\title{
The Influence of Trichoderma on the Phytosanitary Status of Soil and Yield of Red Beets (Beta vulgaris L. subsp. vulgaris)
}

\author{
Agnieszka Wolna-Maruwka ${ }^{1 *}$, Tomasz Piechota ${ }^{2}$, Jacek Dach ${ }^{3}$, \\ Magdalena Szczech ${ }^{4}$, Izabela Szczerbal ${ }^{5}$, Alicja Niewiadomska ${ }^{1}$, \\ Anna Budka ${ }^{6}$, Renata $\mathrm{Gaj}^{7}$ \\ 'Poznań University of Life Sciences, Department of General and Environmental Microbiology, \\ Szydłowska 50, 60-656 Poznań, Poland \\ ${ }^{2}$ Poznań University of Life Sciences, Department of Agronomy, \\ Dojazd 11, 60-656 Poznań, Poland \\ ${ }^{3}$ Poznań University of Life Sciences, Institute of Biosystems Engineering, \\ Wojska Polskiego 50, 60-656 Poznań, Poland \\ ${ }^{4}$ Research Institute of Horticulture, Konstytucji 3 Maja 1/3, 96-100 Skierniewice, Poland \\ ${ }^{5}$ Poznań University of Life Sciences, Department of Genetics and Animal Breeding, \\ Wołyńska 33, 60-637 Poznań, Poland \\ ${ }^{6}$ Poznań University of Life Sciences, Department of Mathematical and Statistical Methods, \\ Wojska Polskiego 28, 60-637 Poznań, Poland \\ ${ }^{7}$ Poznań University of Life Sciences, Department of Agricultural Chemistry and Environmental Biogeochemistry, \\ Wojska Polskiego 38/42, 60-637 Poznań, Poland
}

Received: 29 June 2016

Accepted: 9 September 2016

\begin{abstract}
Our article describes a study on the influence of mineral and organic fertilisation and three strains of Trichoderma sp. isolated from Polish soils on the count of moulds, including the Fusarium and Alternaria genera, as well as the soil fertility index and the yield of red beets. Apart from that, the aim of the study was to assess the interaction between Trichoderma sp. and plant pathogens. A field experiment was performed on haplic luvisols soil in 11 combinations: a control sample, a variant with a mineral fertiliser, one with manure and eight variants where tomato or onion waste composts were applied. Some of them were inoculated with Trichoderma atroviride (T1) and/or T. harzianum (T2 and T3) isolates. The total count of moulds and the counts of Trichoderma sp., Fusarium sp., and Alternaria sp. in the soil were the most strongly influenced by the addition of mineral fertiliser and manure. On the other hand, the values of the soil fertility index were the highest in the soil enriched with manure, followed by the soil combinations with tomato waste composts. Vegetable waste composts applied to the soil proved to be good carriers of Trichoderma sp. isolates. The study did not prove any antagonistic effect of Trichoderma sp. isolates on the proliferation of Alternaria sp.
\end{abstract}

*e-mail: amaruwka@up.poznan.pl 
The growth and development of Fusarium sp. was inhibited by the Trichoderma - T3 strain on its own or in combination with isolate Trichoderma- T1.

The yield of red beet roots and leaves was the highest in the combination with the mineral fertiliser and in the soil fertilised with the composts that had been simultaneously inoculated with two strains, i.e., Trichoderma- T1 and Trichoderma-T2, or Trichoderma- T1 and Trichoderma- T3.

Keywords: compost, moulds, enzymes, soil, plants

\section{Introduction}

In view of human health care and the state of the natural environment, in recent years limited use of pesticides and artificial fertilisers has been a leading trend in crop cultivation. In consequence, the authorities have introduced stricter regulations, which force farmers to reduce the amount of chemical crop protection products to the necessary minimum [1].

On 1 January 2014 the European Union introduced obligatory integrated crop protection. In Poland it was introduced as a regulation of the Minister of Agriculture and Rural Development [2]. According to the rules of integrated crop protection specified in Annex III of Directive 2009/128/EC, 'Sustainable biological, physical, and other non-chemical methods must be preferred to chemical methods if they provide satisfactory pest control' [3].

Trichoderma is a fungal genus regarded as a biological control agent (BCA) [4]. Agricultural biocontrol with Trichoderma is a natural and environmentally friendly alternative to chemical crop protection products that pollute the environment and accumulate toxic substances.

Trichoderma fungi can be used as biopesticides due to their universal effect. These microorganisms belong to the most common soil moulds and are capable of colonizing different environments. It is very easy to isolate them from soil, wood, and other forms of organic matter [5].

The occurrence of Trichoderma sp. is so common in nature because the fungi effectively use available substrates and are capable of secreting enzymes, antibiotics, and other secondary metabolites. For this reason, they can be found in such diversified environments as hot rainforests and sterile, lightproof biotechnological fermenters [6].

The effect of Trichoderma sp. promoting the growth and development of plants and strengthening their resistance to pathogenic organisms is based on a wide range of mechanisms. According to You et al. [4] and Toghueo et al. [7], the antagonistic effect of Trichoderma sp. on plant pathogens (Fusarium sp., Alternaria, sp. Rhizoctonia sp., Phytophthora sp., Pythium sp. Sclerotinia sp.) consists of the production of antibiotics (harzianic acid, tricholine, heptelidic acid, viridine, peptaibols, glyovirin, massoilacton, gliotoxins, alamethicin, 6-pentyl-a-pyrol, glisoprenin), lytic enzymes (cellulase, hemicellulase, xylanase, pectinase, $\beta$-1,3-glucanase, chitinase and protease), and substrate acidification, as well as aggressive competition for living space and nutrients in the substrate.
Moreover, as Trichoderma fungi produce siderophores, they are capable of rapid chelation of the elements, trace amounts of which can be found in the rhizosphere (e.g., iron) and thus they do not make them available to pathogens [8].

According to Mukherjee [9] and Haque et al. [10], Trichoderma sp. stimulate the growth and development of plants by secretion of vitamins and phytohormones. They also participate in increasing the availability of elements necessary for plants - chiefly phosphorus and nitrogen. Apart from that, they provide nutrients to plants by mineralisation of organic matter.

Around the world there are more than 25 biopreparations that contain different fungal species of the Trichoderma genus. At present, biopreparations containing Trichoderma are used for growing soy, beans, cotton, tobacco, tomatoes, and onions. When they are applied to crops, the costs of production are reduced by about $40 \%$ [11].

Apart from one preparation based on the Polish strain of Trichoderma viride, only foreign biopreparations are available in Poland. There are some doubts whether the strains they contain can fully adapt to Polish climate conditions. It seems that the best solution would be to make biopreparations containing domestic strains of Trichoderma sp., which would be effective in our climate conditions. Simultaneously, they would cut the costs of their production [12].

The aim of our study was to analyze the influence of mineral and organic fertilisation and three isolates of Trichoderma sp. on the fertility of soil under a red beet plantation by assessing the dehydrogenases and catalase activity. Apart from this, the aim of the study was to assess the influence of these factors on the count of plant pathogens of the Fusarium and Alternaria genera and on the yield of red beets.

\section{Material and Methods}

\section{Experimental Design}

A two-year experiment was conducted in 2013 and 2014. The experiment was started in a randomised block design in plots of $9.3 \mathrm{~m}^{2}(6 \mathrm{~m} \times 1.55 \mathrm{~m})$ belonging to a private farm in Lubosz, Commune of Kwilcz, Greater Poland Voivodeship, Poland. The experiment was located on typical haplic luvisols formed from light loamy 
sands, deposited in a shallow layer on light loam. The granulometric composition of the soil ranged from light clayey sands to strong sands deposited on light clays. Table 1 shows selected soil characteristics.

The following three Trichoderma isolates were used in the experiment: T. atroviride (T1) and T. harzianum (T2 and T3). They came from the collection of strains of the Institute of Horticulture in Skierniewice, Poland. They were used for the inoculation of composts made from onion and tomato waste and then they were applied to the soil under a red beet plantation (Beta vulgaris L. subsp. vulgaris), Zeppo F1 cultivar.

The composts used in the experiment were produced on a technical scale (in prisms with about 20 tons of input). Both the tomato waste compost and onion waste compost (mostly clusters, leaves, etc.) were mixed with wheat straw (about 10\% added) and a small amount of pig manure $(5 \%)$.

When the thermophilic phase was over (the prism temperature was about $25^{\circ} \mathrm{C}$ ), the composts were inoculated with Trichoderma strains by means of a hand sprayer. At that moment the density of Trichoderma sp. spores entered into the waste composts was $10^{4}$. One month after the inoculation of the composts they were entered into the soil. The following amounts were applied: $43 \mathrm{t} \mathrm{ha}^{-1}$ onion waste compost and $38 \mathrm{t} \mathrm{ha}^{-1}$ tomato waste compost. Apart from that, we also applied pig manure fertilisation $\left(37 \mathrm{t} \mathrm{ha}^{-1}\right)$ and mineral fertilisation with nitrogen as urea (90 $\mathrm{kg} \mathrm{N} \mathrm{ha}^{-1}$ ), with phosphorus as triple superphosphate (40 $\mathrm{kg} \mathrm{P} \mathrm{ha-1)}$ and with potassium as potassium salt $\left(182 \mathrm{~kg} \mathrm{~K} \mathrm{ha}^{-1}\right)$. All organic fertilisers entered into the soil were equivalent to $170 \mathrm{~kg} \mathrm{~N}^{-1}$.

Eleven fertiliser combinations were used in the experiment, with four replications of each combination: 1) control sample (no fertiliser), 2) mineral fertiliser, 3) manure, 4) onion waste compost, 5) onion waste compost inoculated with strain $\mathrm{T} 1,6)$ onion waste compost inoculated with strain $\mathrm{T} 3,7$ ) onion waste compost inoculated with strains $\mathrm{T} 1$ and $\mathrm{T} 3,8)$ tomato waste compost, 9) tomato waste compost inoculated with strain $\mathrm{T} 1,10)$ tomato waste compost inoculated with strain $\mathrm{T} 2$, and 11) tomato waste compost inoculated with strains T1 and $\mathrm{T} 2$.

Both in 2013 and 2014 soil samples necessary for microbiological and biochemical analyses were collected during three periods (10 replications), according to the

Table 1. Chemical characteristics of soil.

\begin{tabular}{|c|c|}
\hline Pure components & $\begin{array}{c}\text { Value } \\
\left(\mathrm{mg} \mathrm{kg}^{-1}\right)\end{array}$ \\
\hline $\mathrm{N}$ & 98.0 \\
\hline $\mathrm{P}$ & 35.31 \\
\hline $\mathrm{K}$ & 73.87 \\
\hline $\mathrm{Mg}$ & 59.12 \\
\hline $\mathrm{pH}$ & 5.9 \\
\hline
\end{tabular}

Polish standard PN - ISO 10381 - 2 : 2007 [13]. Depending on the year of the research, the sample collection dates coincided with the pre-sowing phase (20-21 July; term I), crop emergence phase (12-13 August; term II) and harvesting phase (23-25 October; term III).

\section{Soil Microorganisms}

The total count of moulds as well as the counts of Trichoderma sp., Alternaria sp., and Fusarium sp. were determined in the experiments (in five replications). The microorganisms were cultured with the plate method on solid substrates using appropriate soil solutions and expressed as $\mathrm{cfu}^{-1} \mathrm{DM}$ of soil. The count of moulds in the medium was determined according to Martin [14], with rose bengal and aureomycin added. Plates were incubated for six days at $25^{\circ} \mathrm{C}$. The count of Trichoderma sp. was determined with the plate method, on a modified Martin's medium [14] with chloramphenicol, streptomycin, metalaxyl, and PCNB (pentachloronitrobenzene) added. The plates were exposed to visible light and incubated for seven days at $24^{\circ} \mathrm{C}$. In order to confirm that Trichoderma sp. belonged systematically to the species of Trichoderma harzianum or Trichoderma atroviride, the fungal colonies were inoculated to a PDA substrate (Sigma Aldrich). They were initially identified with a microscope and later the identification was confirmed by means of fluorescent in-situ hybridisation (FISH) [15] with 4\% PFA (paraformaldehyde), $0.5 \%$ Triton solution, alcohol series $(70 \%, 80 \%, 96 \%), 70 \%$ formamide solution, and two probes whose ends were marked with $\mathrm{Cy} 3$ marker (ACT CCC AAA CCC AAT GTG AA and ATA CCA AAC TGT TGC CTCGG) [16].

In the experimental variants where the aforementioned Trichoderma sp. isolates were not applied, but the analyses revealed the presence of native Trichoderma sp. strains in the soil (e.g., in the control sample), only the counts of Trichoderma harzianum and Trichoderma atroviride were determined.

The count of Fusarium sp. was determined with the plate method, on a medium [17] with oxbile, chloramphenicol, streptomycin, borax, and PCNB (pentachloronitrobenzene) added. The plates were incubated for 14 days at $24^{\circ} \mathrm{C}$. The count of Alternaria sp. was determined on a medium developed by Hong and Pryor [18], with 20\% lactic acid, botran (active ingredient: dichloran), bayleton (active ingredient: triadimefon) and streptomycin added, by incubating the plates at $24^{\circ} \mathrm{C}$ for seven days.

The fungal colonies were inoculated to a PDA substrate (Sigma Aldrich) and then identified systematically based on mycological keys [19-21].

\section{Soil Enzymes}

Biochemical analyses were performed by means of spectrophotometry. Dehydrogenase activity (DHA) was determined according to Thalmann [22] with some minor modifications. The soil $(1 \mathrm{~g})$ was incubated for $24 \mathrm{~h}$ with 2, 3, 5-triphenyltetrazolium chloride (TTC) at $30^{\circ} \mathrm{C}$, 
pH 7.4. Triphenylformazan (TPF) was produced, extracted with $96 \%$ ethanol, and measured spectrophotometrically at $485 \mathrm{~nm}$. Dehydrogenases activity was expressed as $\mu \mathrm{mol} \mathrm{TPF} \mathrm{g}^{-1} \mathrm{DM}$ of soil $24 \mathrm{~h}^{-1}$.

Catalyse activity (CAT) in the soil was determined by means of titration [23]. The soil with $0.3 \% \mathrm{H}_{2} \mathrm{O}_{2}$ solution was incubated for 20 minutes and then $1.5 \mathrm{M}$ $\mathrm{H}_{2} \mathrm{SO}_{4}$ was added. The resulting solution was titrated with $0.02 \mathrm{M} \mathrm{KMnO}_{4}$. The catalyse activity was expressed as $\mu \mathrm{mol} \mathrm{H}_{2} \mathrm{O}_{2} \mathrm{~g}^{-1}$ D.M. of soil $\mathrm{min}^{-1}$.

The dehydrogenases and catalyse activity were measured to determine the soil biological index of fertility (BIF) according to Stefanic et al. [24]:

$$
\mathrm{BIF}=(1.5 \mathrm{DHA}+100 k \mathrm{CAT}) / 2
$$

$\ldots$ where $k$ is the proportionality coefficient $=0.01$

\section{Crops}

The crops were harvested manually by collecting two central rows from the plot. The yield of aerial parts and the yield of roots were separately measured. Crop density was measured by counting the plants harvested. After the harvest about $500 \mathrm{~g}$ samples were separated and dried at $55^{\circ} \mathrm{C}$ to a constant weight so as to measure the dry weight content and calculate the yield of dry weight of roots and leaves.

\section{Statistical Analysis}

Statistical analyses were conducted by means of Statistica 12.0 software (StatSoft Inc. 2012). We used twoway analysis of variance to determine the significance of variation in the count of groups of microorganisms under analysis and soil enzymatic activity, depending on the soil combination and term of analysis. Homogeneous subsets of means were identified by means of Tukey's test at a significance level of $p=0.05$.
Pearson's linear correlation coefficient was used to determine the correlation between the count of Trichoderma sp. and soil $\mathrm{pH}$, and principal component analysis (PCA) was used to illustrate the dependence between the count of microorganisms in the soil. In order to group the items according to the mean values of all the variables, i.e., individual soil combinations at consecutive terms, a cluster analysis of the data was made by means of the 'Agricolae' package $(\mathrm{R})$.

\section{Results and Discussion}

\section{Soil Microorganisms}

According to Ahemad and Khan [25], soil microorganisms are thought to play a key role in controlling the reactions that are necessary to maintain soil structure and fertility. Their interaction with higher plants results in a specific equilibrium in the soil biocenosis, which may be disturbed by a flow of organic matter, chemical substances, or a sudden change in the physiochemical properties of soil.

Apart from eubacteria and actinobacteria, moulds play a vital role in the circulation of nutrients in soil. From the agricultural point of view, they have an important function in the processes of plant nutrition due to their physiological ability to accumulate water, produce organic acids, and release a wide range of nutrients from soil minerals [26].

Having averaged the results of microbiological analyses from the two consecutive years of the study, we obtained the results concerning the influence of the type of fertilisation and term of collection of soil samples on the count and activity of soil microorganisms (Table 2). The two-way analysis of variance, with the type of fertilisation and term of collection of samples of soil under a red beet plantation being the factors affecting the traits under study, proved that both factors had highly significant influence

Table 2. Microorganism numbers in soil with fertilizer addition, in three terms of analysis.

\begin{tabular}{|c|c|c|c|c|}
\hline \multirow{2}{*}{$\begin{array}{l}\text { Experimental } \\
\text { combination }\end{array}$} & \multicolumn{4}{|c|}{ Microorganisms (cfu g-1 DM soil) } \\
\hline & $\begin{array}{l}\text { Total number of moulds } \\
\qquad\left(10^{3} \mathrm{cfu}\right)\end{array}$ & $\begin{array}{l}\text { Trichoderma sp } \\
\quad\left(10^{2} \mathrm{cfu}\right)\end{array}$ & $\begin{array}{l}\text { Fusarium sp } \\
\text { (cfu) }\end{array}$ & $\begin{array}{c}\text { Alternaria } \mathrm{sp} \\
\text { (cfu) }\end{array}$ \\
\hline \multicolumn{5}{|c|}{ Term I } \\
\hline 1 & $9.73^{\mathrm{abc}}$ & $0.36^{\mathrm{abc}}$ & $43.71^{\mathrm{a}}$ & $67.00^{\mathrm{a}-\mathrm{d}}$ \\
\hline 2 & $18.68^{\mathrm{a}-\mathrm{e}}$ & $0.35^{\mathrm{abc}}$ & $93.45^{\mathrm{ab}}$ & $1.22^{\mathrm{a}}$ \\
\hline 3 & $15.42^{\mathrm{a}-\mathrm{e}}$ & $0.34^{\mathrm{abc}}$ & $21.55^{\mathrm{a}}$ & $14.43^{\mathrm{abc}}$ \\
\hline 4 & $2.15^{\mathrm{ab}}$ & 0.00 & 0.00 & $51.44^{\mathrm{a}-\mathrm{d}}$ \\
\hline 5 & $1.43^{\mathrm{a}}$ & 0.00 & $21.54^{\mathrm{a}}$ & 0.00 \\
\hline 6 & $21.49^{\mathrm{a}-\mathrm{f}}$ & 0.00 & $50.086^{\mathrm{cd}}$ & 0.00 \\
\hline 7 & $2.14^{\mathrm{ab}}$ & 0.00 & $586.11^{\mathrm{d}}$ & 0.00 \\
\hline 8 & $2.52^{\mathrm{ab}}$ & 0.00 & $14.34^{\mathrm{a}}$ & $10.06^{\mathrm{e}}$ \\
\hline
\end{tabular}


Table 2. Continued.

\begin{tabular}{|c|c|c|c|c|}
\hline 9 & $2.87^{\mathrm{ab}}$ & 0.00 & $179.22^{\mathrm{ab}}$ & $17.79^{\mathrm{abc}}$ \\
\hline 10 & $4.30^{\mathrm{ab}}$ & 0.00 & $43.10^{\mathrm{a}}$ & 0.00 \\
\hline 11 & $12.22^{\mathrm{a}-\mathrm{d}}$ & 0.00 & $104.22^{\mathrm{ab}}$ & $53.39^{\mathrm{a}-\mathrm{d}}$ \\
\hline \multicolumn{5}{|c|}{ Term II } \\
\hline 1 & $22.79^{\mathrm{a}-\mathrm{g}}$ & $0.18^{\mathrm{ab}}$ & $167.56^{\mathrm{ab}}$ & $49.99^{a-d}$ \\
\hline 2 & $37.78^{\mathrm{e}-\mathrm{i}}$ & $3.92^{\mathrm{e}}$ & $135.44^{\mathrm{ab}}$ & $21.14^{\mathrm{a}-\mathrm{d}}$ \\
\hline 3 & $22.88^{\mathrm{a}-\mathrm{g}}$ & $1.60^{\mathrm{a}-\mathrm{d}}$ & $86.67^{\mathrm{ab}}$ & $39.88^{a-d}$ \\
\hline 4 & $23.96^{\mathrm{a}-\mathrm{g}}$ & $1.75^{\mathrm{a}-\mathrm{d}}$ & $72.33^{\mathrm{ab}}$ & $50.16^{\mathrm{a}-\mathrm{d}}$ \\
\hline 5 & $20.29^{\mathrm{a}-\mathrm{g}}$ & $1.83^{\mathrm{a}-\mathrm{e}}$ & $79.21^{\mathrm{ab}}$ & $89.68^{\text {cd }}$ \\
\hline 6 & $20.15^{\mathrm{a}-\mathrm{g}}$ & $2.50^{\text {de }}$ & $72.33^{\mathrm{ab}}$ & $7.95^{\mathrm{cd}}$ \\
\hline 7 & $19.71^{\mathrm{a}-\mathrm{e}}$ & $1.77^{\mathrm{a}-\mathrm{d}}$ & $78.11^{\mathrm{ab}}$ & $24.78^{\mathrm{a}-\mathrm{d}}$ \\
\hline 8 & $18.41^{\mathrm{a}-\mathrm{e}}$ & $1.45^{\mathrm{a}-\mathrm{d}}$ & $68.67^{\mathrm{ab}}$ & $25.63^{\mathrm{a}-\mathrm{d}}$ \\
\hline 9 & $21.68^{\mathrm{a}-\mathrm{f}}$ & $0.94^{\mathrm{a}-\mathrm{d}}$ & $71.71^{\mathrm{ab}}$ & $3.16^{\mathrm{ab}}$ \\
\hline 10 & $30.62^{\mathrm{c}-\mathrm{h}}$ & $2.28^{\mathrm{b}-\mathrm{e}}$ & $87.72^{\mathrm{ab}}$ & $69.15^{\mathrm{a}-\mathrm{d}}$ \\
\hline 11 & $21.53^{\mathrm{a}-\mathrm{f}}$ & $2.32^{\mathrm{b}-\mathrm{e}}$ & $128.68^{\mathrm{ab}}$ & $17.79^{a b c}$ \\
\hline \multicolumn{5}{|c|}{ Term III } \\
\hline 1 & $45.87^{\mathrm{g}-\mathrm{i}}$ & $0.31^{\mathrm{ab}}$ & $189.00^{\mathrm{ab}}$ & $78.65^{\mathrm{cd}}$ \\
\hline 2 & $54.19^{i}$ & $0.78^{\mathrm{abc}}$ & $296.53^{\mathrm{bc}}$ & $81.99^{\mathrm{cd}}$ \\
\hline 3 & $45.34^{\mathrm{g}-\mathrm{i}}$ & $1.81^{\mathrm{a}-\mathrm{e}}$ & $291.19^{\mathrm{bc}}$ & $66.74^{\mathrm{a}-\mathrm{d}}$ \\
\hline 4 & $43.30^{\mathrm{g}-\mathrm{i}}$ & $0.96^{\mathrm{a}-\mathrm{d}}$ & $167.44^{\mathrm{ab}}$ & $33.24^{\mathrm{a}-\mathrm{d}}$ \\
\hline 5 & $51.05^{\mathrm{hi}}$ & $0.83^{\mathrm{abc}}$ & $81.05^{\mathrm{ab}}$ & $60.30^{a-d}$ \\
\hline 6 & $37.21^{\mathrm{e}-\mathrm{i}}$ & $1.01^{\mathrm{a}-\mathrm{d}}$ & $97.45^{\mathrm{ab}}$ & $19.32^{\mathrm{a}-\mathrm{d}}$ \\
\hline 7 & $35.21^{\mathrm{e}-\mathrm{i}}$ & $3.08^{\mathrm{e}}$ & $92.25^{\mathrm{ab}}$ & $23.43^{\mathrm{a}-\mathrm{d}}$ \\
\hline 8 & $25.19^{\mathrm{b}-\mathrm{g}}$ & $1.20^{\mathrm{a}-\mathrm{d}}$ & $78.99^{\mathrm{ab}}$ & $39.81^{\mathrm{a}-\mathrm{d}}$ \\
\hline 9 & $21.11^{\mathrm{a}-\mathrm{f}}$ & $1.06^{\mathrm{a}-\mathrm{d}}$ & $42.28^{\mathrm{ab}}$ & $44.35^{\mathrm{a}-\mathrm{d}}$ \\
\hline 10 & $32.52^{\mathrm{c}-\mathrm{i}}$ & $1.31^{\mathrm{a}-\mathrm{d}}$ & $74.32^{\mathrm{ab}}$ & $34.16^{\mathrm{a}-\mathrm{d}}$ \\
\hline 11 & $29.61^{\mathrm{c}-\mathrm{h}}$ & $0.99^{\mathrm{a}-\mathrm{d}}$ & $181.18^{\mathrm{ab}}$ & $2.87^{\mathrm{a}-\mathrm{d}}$ \\
\hline
\end{tabular}

Explanation: Means followed by the same letters do not differ significantly at $p=005$; Combination: 1 - control sample (no fertilizer), 2 - mineral fertilizer, 3 - manure, 4 - onion waste compost, 5 - onion waste compost inoculated with strain T1, 6 - onion waste compost inoculated with strain T3, 7 - onion waste compost inoculated with strains T1 and T3,8 - tomato waste compost, 9 - tomato waste compost inoculated with strain T1,10 - tomato waste compost inoculated with strain T2, 11 - tomato waste compost inoculated with strains T1 and T2; Terms: I - the pre-sowing phase, II - crop emergence phase, III - harvesting phase.

on the count of the microorganisms under analysis and enzymatic activity of soil (Table 3, Fig. 1).

The quantitative analysis of moulds in the 11 experimental combinations revealed that the soil was most strongly colonized with these microorganisms at the phase of harvest (the third term) - especially in the soil where mineral fertilisation was applied (combination 2). Reference publications emphasize the stimulating effect of mineral fertilisation on the life of soil microflora, as it increases the count of microorganisms [26-27].

The analysis of data in Table 2 shows that regardless of the type of fertilizing combination, the lowest total count of moulds was observed at the first term of analyses (before sowing) - especially in the soil enriched with onion waste compost that had been inoculated with strain T1 (combination 5). It is most likely that the low count of moulds at that term was caused by the absence of plants, which were sown only after soil samples had been collected. According to Vallance et al. [28], the count of soil microorganisms is considerably modified by plant root secretions. Their qualitative and quantitative composition depends not only on the plant species but also on the stage of plant development.

The fertilisers applied in the experiment also significantly modified the count of moulds in the soil. As far as the mean value from the three consecutive 
Table 3. $F$ test statistics and significance levels of two-way analysis of variance for the number of selected groups of microorganisms associated; with soil combination and terms research fixed factors $(* * * p=0001, * * p=001, * p=005)$.

\begin{tabular}{|c|c|c|c|}
\hline Parameter & Term & Combination & Interaction \\
\hline Moulds & $59.98^{* * *}$ & $3.29 * *$ & $3.26^{* * *}$ \\
\hline Trichoderma sp. & $142.92 * * *$ & $6.59 * * *$ & $2.51^{* *}$ \\
\hline Fusarium $\mathrm{sp}$. & $5.05^{* *}$ & $7.14 * * *$ & $10.15^{* * *}$ \\
\hline Alternaria $\mathrm{sp}$. & $\mathbf{4 . 8 0 *}$ & $\mathbf{2 . 9 2} * *$ & $\mathbf{4 . 4 8}^{* * *}$ \\
\hline BIF & $\mathbf{3 0 . 7 5}^{*}$ & $\mathbf{4 . 9 8}^{* * *}$ & $\mathbf{1 . 8 6}^{* * *}$ \\
\hline
\end{tabular}

terms of analyses is concerned, the greatest count of the microorganisms was noted after mineral fertilization $\left(36.88 \cdot 10^{3} \mathrm{cfu} \cdot \mathrm{g}^{-1} \mathrm{dm}\right.$ soil) followed by manure fertilization $\left(27.87 \cdot 10^{3} \mathrm{cfu} \cdot \mathrm{g}^{-1} \mathrm{dm}\right.$ soil). Kucharski and Wyszkowska [29] report that the effect of mineral fertilizers (especially physiologically acidic ones) on soil microorganisms results from their direct influence on $\mathrm{pH}$ variation in the environment. On the other hand, the authors stress the fact that the tendencies of changes in the microflora, which take place after mineral fertilization, are much less than those resulting from the application of fertilizers improving the content of organic matter in soil, i.e., fertilization with manure, liquid manure, or straw.

In most cases the composts made from onion or tomato waste reduced the count of moulds. On average the count dropped by $12 \%$ when the composts made from onion

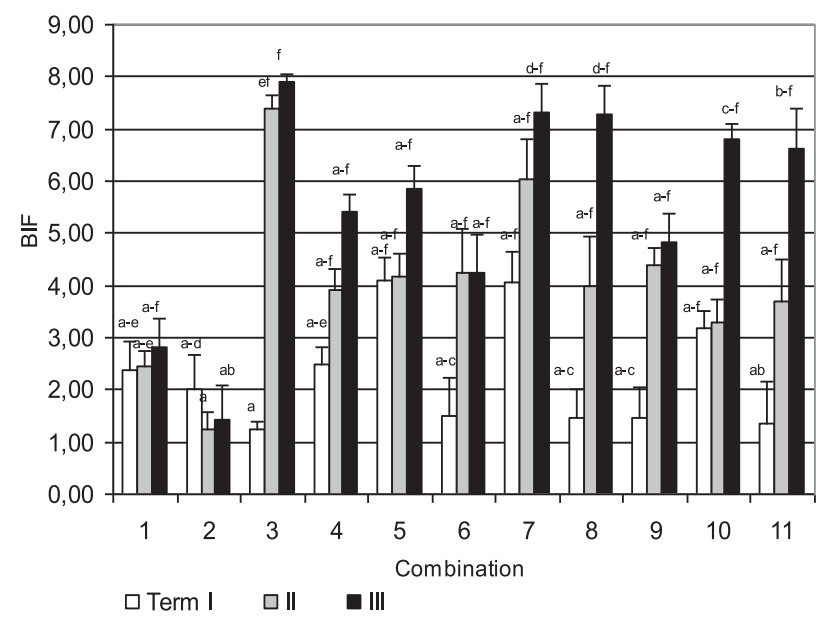

Fig. 1. The changes of Biological Index of Fertility (BIF) in a soil. Explanation: Means followed by the same letters do not differ significantly at $p=0.05$; Combination: $1-$ control sample (no fertilizer), 2 - mineral fertilizer, 3 - manure, 4 - onion waste compost, 5 - onion waste compost inoculated with strain T1, $6-$ onion waste compost inoculated with strain T3, 7 - onion waste compost inoculated with strains $\mathrm{T} 1$ and $\mathrm{T} 3,8$ - tomato waste compost, 9 - tomato waste compost inoculated with strain T1, 10 - tomato waste compost inoculated with strain T2, 11 - tomato waste compost inoculated with strains T1 and T2; Terms: I - the pre-sowing phase, II - crop emergence phase, III - harvesting phase. waste were applied and by $26 \%$ when those made from tomato waste were used (combinations 8-11).

The lower count of moulds in the soil with the aforementioned composts may have been caused by the occurrence of antagonistic phenomena related to nutrients or place of colonization between the autochthonic soil microflora and zymogenous microorganisms entered into the soil with the composts [30-31].

Apart from that, the decrease in the count of moulds may also have been caused by the chemical composition of the composts entered into the soil. During the decomposition of plant debris in the composts many different substances exhibiting strong biological properties may have been released, such as phenols, aldehydes, alcohols, essential oils, terpenes, or acids with an inhibitory effect on soil microorganisms [32]. According to Steinka and Kukułowicz [33], caffeic acid is an example of a substance with antimicrobial properties that can be found in tomato tissues.

As results from the data in Table 2, the type of experimental combination and the term of sample collection had significant influence on variability in the count of Trichoderma sp. The research revealed that there were considerable fluctuations in the count of these microorganisms during the whole research period. As results from the analysis of mean values in individual experimental items, the presence of these microorganisms was noted only at the second (the phase of plant emergence) or third term of analyses (the harvest phase). Trichoderma sp. are fungi that can mostly be found in the root zone. This fact may have caused their presence at the phase of beet emergence and harvesting also in the soil items where Trichoderma sp. isolates had not been entered. According to You et al. [4], the adhesion of these fungi to hydrophobic root surfaces is conditioned by the production of proteins - hydrophobins that affect their effective colonization.

The results of our study indicate that the development of these fungi was statistically significantly activated in the combination where mineral fertilization had been applied. Manure and the composts also caused an increase in the count of Trichoderma sp. in the soil. Apart from that, the analysis revealed that the count of Trichoderma sp. was greater and their population developed better after the addition of the onion rather than tomato waste composts into the soil. The growth was particularly noticeable in the combination where the compost had been simultaneously inoculated with two strains of Trichoderma sp.: T1 and T3 (combination 7).

As Lee [34] reports, agrotechnical treatments applied during crop cultivation, such as mineral nitrogen fertilization and organic fertilization, stimulate the count and activity of soil microorganisms. However, there are also studies that reported that fertilization reduced the total microbial biomass [35]. The negative effects of fertilization may have been caused by direct toxicity and changes in $\mathrm{pH}$ due to ammonium-based fertilizers. According to Heinze et al. [36], the application of mineral fertilizers resulted in a significantly decreased soil $\mathrm{pH}$, which is an important regulator of the development of 


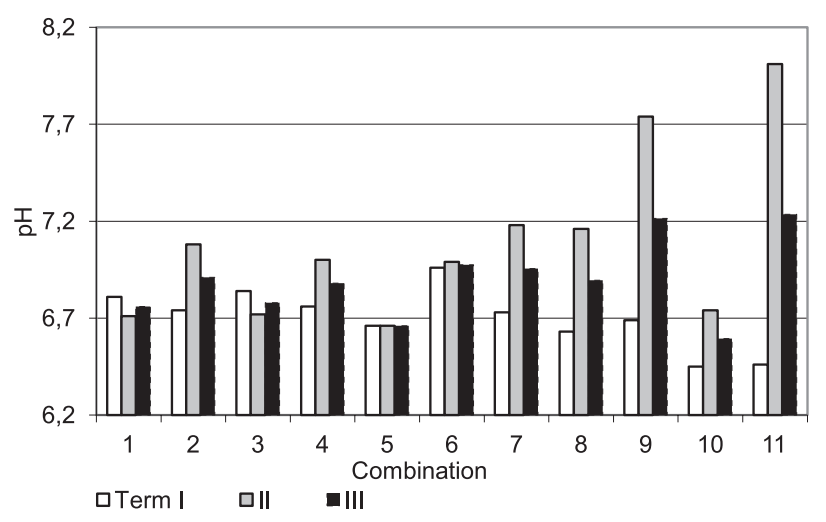

Fig. 2. Changes in $\mathrm{pH}$ value in soil combinations (explanation as in Fig. 1).

soil microorganisms because it affects the solubility of various mineral substances, simultaneously influencing their absorbability. Therefore, the $\mathrm{pH}$ value (Fig. 2) and its influence on the development of Trichoderma sp. were determined in our study (Table 4).

As results from the research by Kredics et al. [31], Trichoderma strains were able to grow in a wide range of $\mathrm{pH}$ values: from 2.0 to 6.0 , with an optimum at 4.0. In our study in most of the combinations the $\mathrm{pH}$ values of the soil under the beet plantation ranged from slightly acidic to alkaline (Fig. 2). The statistical analysis based on Pearson's linear correlation coefficient proved that the count of Trichoderma sp. was positively correlated with the $\mathrm{pH}$ value in the experimental combinations, except for the soil fertilized with manure (Table 4).

In order to confirm the phytosanitary properties of Trichoderma sp. fungi in the experiment we also analyzed the count of fungal pathogens of the Alternaria and Fusarium genera in the soil (Table 2). Alternaria and Fusarium fungi are the most common pathogens isolated from crops all over the world. Due to their high pathogenicity and toxigenicity (especially the Fusarium genus), they are considered to be the most dangerous filamentous fungi causing enormous economic loss [37].

The microbial analyses conducted as part of our study revealed the presence of Fusarium fungal pathogens (1.12$58.61 \mathrm{cfu}$ per $1 \mathrm{~g}$ of dry weight) in all soil combinations at the first term of the study, i.e., before fertilizing the soil. The greatest amount of the fungi was found in the plots where onion-waste composts were to be applied (combinations 6 and 7). Apart from that, the sanitary analysis at the first term of investigations also revealed that the soil was contaminated with Alternaria sp. fungi. However, these pathogens were not found in all soil combinations and the contamination with Alternaria sp. was not as heavy as with Fusarium sp. (1.43-10.06 cfu per $1 \mathrm{~g}$ of dry weight of soil).

At the phase of plant emergence (the second term) the presence of Alternaria sp. was noted in all experimental variants. There was also considerable fluctuation in the count of these microorganisms between the second and third terms of investigations, depending on the experimental combination. Alternaria sp. can survive as mycelium or spores on decaying plant debris for a considerable time, or as a latent infection in seeds. If seedborne, the fungus can attack the seedling once the seed has germinated. In other cases, once the spores are produced, they are mainly spread by wind onto plant surfaces, where infection can occur [38].

During the experiment the count of Fusarium sp. increased in most of the experimental variants. It was probably caused by the presence of plants and their root secretions.

Similarly to the aforementioned total count of moulds, Trichoderma sp., Fusarium sp., and Alternaria sp. also responded to fertilization with statistically significant

Table 4. Pearson correlation coefficient between the number of microorganisms and soil $\mathrm{pH}$ value.

\begin{tabular}{|c|c|c|c|c|}
\hline Combination & Moulds & Trichoderma sp. & Fusarium sp. & Alternaria sp. \\
\hline 1 & -0.36 & $0.97^{*}$ & $-0.79^{*}$ & 0.59 \\
\hline 2 & 0.54 & $0.91^{*}$ & 0.20 & -0.49 \\
\hline 3 & -0.24 & $-0.79^{*}$ & -0.23 & -0.27 \\
\hline 4 & 0.53 & $0.98^{*}$ & 0.43 & $0.75^{*}$ \\
\hline 5 & -0.14 & $0.89^{*}$ & 0.47 & $0.96^{*}$ \\
\hline 6 & -0.07 & $0.99^{*}$ & $-0.89^{*}$ & $0.89^{*}$ \\
\hline 7 & 0.53 & 0.57 & $-0.88^{*}$ & $-0.94^{*}$ \\
\hline 8 & $0.68^{*}$ & 0.94 & $0.78^{*}$ & -0.35 \\
\hline 9 & $0.88^{*}$ & $0.81^{*}$ & $-0.75^{*}$ & $0,98^{*}$ \\
\hline 10 & $0.83^{*}$ & $0.98^{*}$ & $0.98^{*}$ & $-0.97^{*}$ \\
\hline
\end{tabular}

*Correlation coefficient significant at significance level $p=005$ 
Table 5 . The sanitary state of composts applied to soil.

\begin{tabular}{|c|c|c|c|c|c|c|c|c|}
\hline \multirow{2}{*}{ Microorganisms } & \multicolumn{8}{|c|}{ Type of compost } \\
\hline & $\mathrm{T}$ & TT1 & TT2 & $\mathrm{TT} 1+\mathrm{T} 2$ & $\mathrm{O}$ & OT1 & OT3 & $\mathrm{OT} 1+\mathrm{T} 3$ \\
\hline $\begin{array}{l}\text { Total number of moulds } \\
\quad\left(10^{4} \mathrm{cfu} \mathrm{g}^{-1} \mathrm{DM}\right)\end{array}$ & 2.45 & 18.12 & 83.24 & 61.78 & 3.45 & 187.65 & 66.23 & 273.01 \\
\hline $\begin{array}{l}\text { Trichoderma sp } \\
\left(10^{2} \text { cfu g }^{-1} \mathrm{DM}\right)\end{array}$ & 2.18 & 22.99 & 4.21 & 30.06 & 0 & 1.98 & 1.11 & 1.32 \\
\hline $\begin{array}{l}\text { Fusarium sp } \\
\left(\text { cfu g }^{-1} \mathrm{DM}\right)\end{array}$ & 0 & 0 & 0 & 0 & 0 & 0 & 0 & 0 \\
\hline $\begin{array}{l}\text { Alternaria } \mathrm{sp} \\
\text { (cfu g-1 DM) }\end{array}$ & 0 & 0 & 0 & 0 & 0 & 0 & 0 & 0 \\
\hline
\end{tabular}

Explanation: T - tomato waste compost, TT1 - tomato waste compost inoculated with strain T1, TT2 - tomato waste compost inoculated with strain $\mathrm{T} 2$, TT1+T2 - tomato waste compost inoculated with strains T1and T2, O - onion waste compost, OT1 - onion waste compost inoculated with strain T1, O3 - onion waste compost inoculated with strain $\mathrm{T} 3, \mathrm{OT} 1+\mathrm{T} 3$ - onion waste compost inoculated with strains $\mathrm{T} 1$ and $\mathrm{T} 3$.

changes in their count. This observation was also confirmed by statistical analysis (Table 3 ). As it revealed, when the mineral fertilizer (combination 2), manure (combination 3), and onion waste composts (combinations 4-7) were applied at the second term of the investigations, the count of Alternaria sp. was even more than 10 times greater than at the first term. In most combinations (except combinations 5, 7, and 9) the count of Fusarium sp. also increased a few times at the second term.

The sanitary analysis of composts and manure conducted before applying them to the soil (Table 5) did not reveal the presence of plant pathogens, so they could not have contaminated it. Thus, it can be concluded that the fertilisation stimulated the proliferation of pathogens in the soil, and the plant debris in the manure and composts was an attractant for Fusarium sp. and Alternaria sp. Apart from that, the increased count of Fusarium sp. at the second term of the investigations in the control sample may indicate that the proliferation of these microorganisms may have been caused by the type of crops cultivated. Studies by Wolna-Maruwka et al. [39] prove that organic fertilization (with sewage sludge) promotes the growth and development of mould populations in soil. However, this view is not supported by the observations made by Górska and Stępien [40], who claimed that the application of organic additives to soil under a beetroot plantation had no effect on the fungal hyphae population. However, the incubation of onion waste composts in the soil for 71-73 days decreased the count of Alternaria sp. It was particularly noticeable in the combination with isolate T3. This phenomenon could be explained by the occurrence of antagonistic interaction between Trichoderma sp. and Alternaria sp. strains or by the slow, inhibitory effect of compost components on the development of these pathogens.

As results from the study by Tagoe et al. [41], onion extracts inhibit some types of moulds because they contain alliin, its homologues (methylalliin and propylalliin), quercetin, and essential oil (which consists chiefly of n-propyl disulphide).
The count of Alternaria sp. in the soil combinations where the tomato waste composts were applied varied in a different way than in the combinations with the other fertilizers. When the composts were applied, the count of Alternaria sp. decreased (except combination 10). This phenomenon may have been caused by the occurrence of antagonism between the native microflora in the composts and the pathogens.

The inhibiting effect of organic fertilizers on the growth of soil pathogens is relatively well documented in literature. Stone et al. [42] demonstrated that organic additives composted with bark and those not subjected to composting inhibited the growth of soil pathogens.

However, further incubation of onion waste composts in the soil increased the proliferation of Alternaria sp. The count of Fusarium sp. also increased in most of the experimental variants and reached maximum values at the third term of the investigations (the harvesting phase). However, the sanitary analysis of the soil revealed that the addition of onion waste compost inoculated with isolate T3 (combination 6) and a mixture of strains $\mathrm{T} 1$ and $\mathrm{T} 3$ (combination 7) contributed to a statistically significant decrease in the count of Fusarium sp. in the soil.

A simple correlation analysis and principal component analysis (PCA) were used to estimate cause-and-effect relationships between the parameters under investigation (Fig. 3). The PCA was used to show regularities between independent variables (the correlation between the count of fungi in individual fertilizer variants) and it consisted in calculating the components being a linear combination of the variables under analysis. Detailed analysis of principal components presents the possibility of showing the initial variables, which are a reference system for the other variables. It is necessary to stress the fact that in the new coordinate system a considerable part of variables can be explained, i.e., more than 55\%.

This statistical analysis points to the inhibitory effect of Trichoderma sp. fungi on the growth and development of Fusarium sp., and it shows that Trichoderma sp. do not 


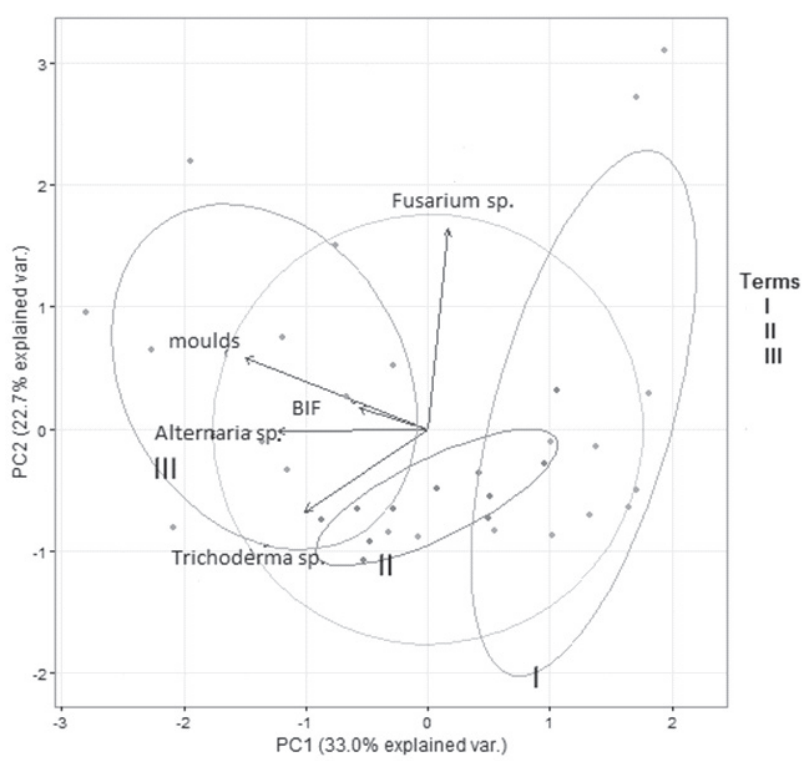

Fig. 3. Dependences between the number of groups of microorganisms applied in the experimental soil combinations at consecutive terms of analyses (PCA).

have an antagonistic effect on the count of Alternaria sp. pathogens.

In order to compare the reactions of the groups of microorganisms under analysis to the type of fertilizer applied at consecutive terms of the investigations we illustrated the data with heat maps, where two-dimensional variables were represented by colours (Fig. 4). As results from the map, there were variations in the structure of similarities concerning the effect of individual fertilizers on the total count of moulds and the counts of Trichoderma sp., Fusarium sp., and Alternaria sp. at consecutive terms. We applied cluster analysis to group the reactions of the microorganisms under study to fertilization so that the degree of related reactions would be the greatest within one group and the smallest between the groups. We used Ward's hierarchical clustering and Euclidean distance. As a result, we obtained a tree diagram grouped into five clusters. The first group was characterized by a similar count of microorganisms at the third term of analyses in the control sample and in the combinations with the mineral fertilizer, manure, and onion waste composts. The second group comprised analogical reactions of the microorganisms in the combination fertilised with manure at the phase of plants' emergence (the second term) and in the soil enriched with the tomato waste composts at the harvest phase (the third term). Apart from that, the microorganisms exhibited similar reactions to mineral fertilization (the first term), manure (the first term), tomato waste composts (the first and second terms), and onion waste composts (the second term). The fourth group was characterized by similar counts of microorganisms at the first term in the control sample, in the soil with the mineral fertilizer and in the soil fertilized with the tomato waste composts, but at the phase of the plants' emergence. The next cluster included a comparable count of microorganisms in the soil enriched with the onion waste composts at the first term of investigations.

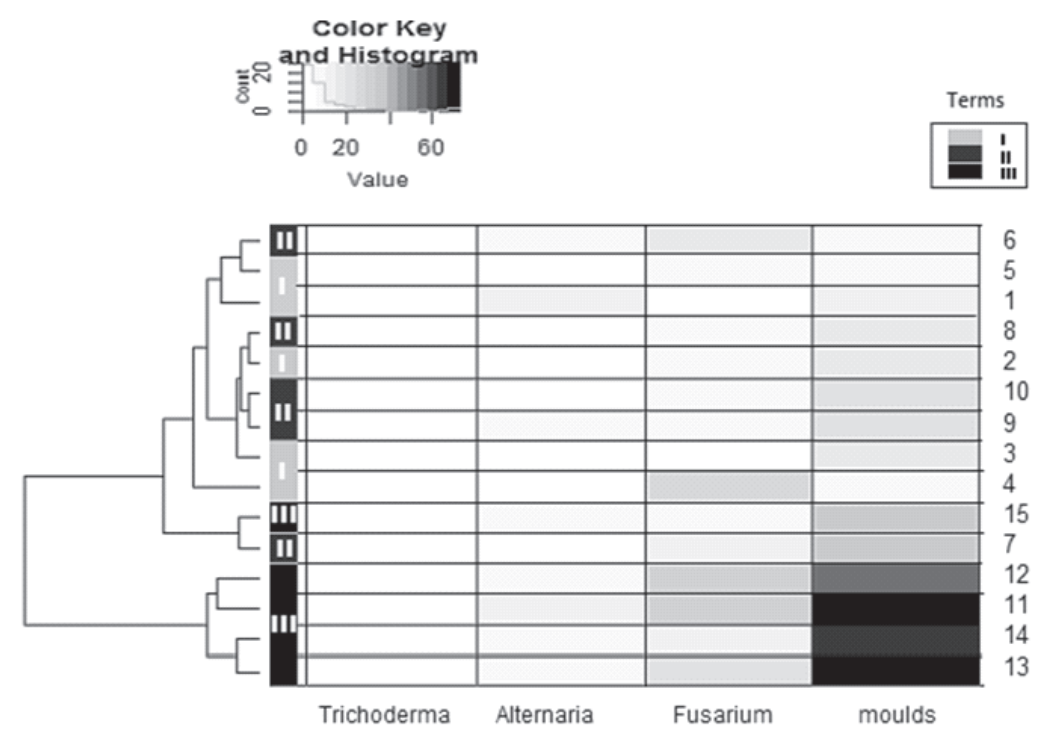

Fig. 4. Comparable reactions of the groups of microorganisms under analysis to the type of fertilizer applied at consecutive terms of investigations. Explanation: 1 - control sample (term I), 2 - mineral fertilizer (term I), 3 - manure (term I), 4 - onion waste compost (term I; average of four combinations with the onion compost and Trichoderma isolates addition), 5 - tomato waste compost (term I; average of four combinations with the tomato compost and Trichoderma isolates addition), 6 - control sample (term II), 7 - mineral fertilizer (term II), 8 - manure (term II), 9 - onion waste compost (term II; average of four combinations with the onion compost and Trichoderma isolates addition), 10 - tomato waste compost (term II; average of four combinations with the tomato compost and Trichoderma isolates addition), 11 - control sample (term III), 12 - mineral fertilizer (term III), 13 - manure (term I), 14 - onion waste compost (term III; average of four combinations with the onion compost and Trichoderma isolates addition), 15 - tomato waste compost (term III; average of four combinations with the tomato compost and Trichoderma isolates addition). 


\section{Soil Enzymes}

When fertilisers or microorganisms in microbial preparations are applied to soil, they may disorder the biological equilibrium, causing variation in the populations of microorganisms and their activity. Some soil enzymes (catalase and dehydrogenases) are used to investigate the metabolic activity of microorganisms or their overall functioning. Both catalase and dehydrogenases are active only inside living cells as they rapidly become degraded when outside [43].

According to Meena et al. [44], the analysis of soil activity of these enzymes presents the possibility of drawing conclusions about the content of organic substance or fertility of the substrate. In our study (Fig. 1) in most of the soil variants (except the combination with the mineral fertiliser), the lowest BIF values - ranging between 1.24 and 4.09 - were observed at the first term of the investigations. The highest values of the index were noted in the plots where the onion waste composts inoculated with strain $\mathrm{T} 1$ and a mixture of strains $\mathrm{T} 1$ and T3 were to be applied, i.e., combination 5 (4.09) and combination 7 (4.07), respectively. When the fertilizers were applied to the soil, the BIF value increased in most of the soil combinations except the one where the mineral fertilizer was applied. According to Acosta-Martinez and Tabatabai [45], in spite of the fact that mineral fertilization positively affects the physiochemical properties of soil, it may reduce its enzymatic activity due to the presence of easily absorbable forms of mineral compounds.

It is most likely that the increase in the BIF values observed in most of the soil variants at the second term of the investigations was caused both by the addition of fertilizers and the presence of plants. This index value in the control sample (2.49) also points to this observation.
Wolna-Maruwka et al. [46] in their study on sage also observed increased DHA activity at the phase of vegetative growth. According to Vallence et al. [28], there are qualitative and quantitative differences in root secretions, which depend on the plant species and cultivar, its phase of development and abiotic factors (such as light, $\mathrm{pH}$, substrate humidity and the content of nutrients in the substrate). These differences modify both the count of soil microorganisms and their activity. Apart from that, according to Yao et al. [47], the plant root system functions as a type of drainage, which enables oxygenation of the substrate, thus stimulating the activity of soil enzymes. The analysis of the BIF at the last term of the investigations showed a further increase in its values in all the combinations under study. The BIF value was most modified by the addition of manure, which caused it to increase up to 7.91 at the harvest phase. At the third term of the investigations the BIF value was also strongly influenced by the addition of tomato waste composts. At the harvest phase this increased to 7.91. The index value at the third term of the investigations was also strongly influenced by the addition of tomato waste composts - at the harvest phase the BIF increased to 4.81-7.27. These observations were also confirmed by Watts et al. [48] and Meena et al. [49] in their studies. They found that the DHA in organically fertilized soil with manure was greater than in the soil where a mineral fertilizer had been applied.

\section{Crop Plants}

Fertilization is one of the most significant factors affecting yield. Appropriate dosage and balance of nutrients are decisive to the yield volume. Natural and organic fertilizers are valuable sources of nutrients because they contain all macro- and microelements,

Table 6. Plant population (No m ${ }^{-2}$ ) and yield of roots and leaves of red beets as affected by fertilization; mean from 2013-14 (Mg ha'-1).

\begin{tabular}{|c|c|c|c|c|c|}
\hline \multirow{2}{*}{$\begin{array}{c}\text { Experimental } \\
\text { combination }\end{array}$} & \multirow{2}{*}{ Plant population } & \multicolumn{4}{|c|}{ Yield } \\
\cline { 3 - 6 } & & Roots & $\begin{array}{c}\text { Roots } \\
\text { dry matter }\end{array}$ & Leaves & $\begin{array}{c}\text { Leaves } \\
(\text { dry matter })\end{array}$ \\
\hline 1 & $22.7^{\mathrm{a}}$ & $11.3^{\mathrm{b}}$ & $1.76^{\mathrm{b}}$ & $10.6^{\mathrm{b}}$ & $1.18^{\mathrm{b}}$ \\
\hline 2 & $23.2^{\mathrm{a}}$ & $18.6^{\mathrm{a}}$ & $2.79^{\mathrm{a}}$ & $18.3^{\mathrm{a}}$ & $1.89^{\mathrm{a}}$ \\
\hline 3 & $17.8^{\mathrm{a}}$ & $15.5^{\mathrm{ab}}$ & $2.38^{\mathrm{ab}}$ & $11.7^{\mathrm{b}}$ & $1.1^{\mathrm{b}}$ \\
\hline 4 & $20.1^{\mathrm{a}}$ & $13.5^{\mathrm{ab}}$ & $2.15^{\mathrm{ab}}$ & $11.2^{\mathrm{b}}$ & $1.1^{\mathrm{b}}$ \\
\hline 5 & $22.9^{\mathrm{a}}$ & $14.8^{\mathrm{ab}}$ & $2.38^{\mathrm{ab}}$ & $12.2^{\mathrm{b}}$ & $1.2^{\mathrm{b}}$ \\
\hline 6 & $17.4^{\mathrm{a}}$ & $15.4^{\mathrm{ab}}$ & $2.31^{\mathrm{ab}}$ & $11.5^{\mathrm{b}}$ & $1.3^{\mathrm{b}}$ \\
\hline 7 & $20.8^{\mathrm{a}}$ & $17.0^{\mathrm{a}}$ & $2.65^{\mathrm{a}}$ & $12.3^{\mathrm{b}}$ & $1.51^{\mathrm{ab}}$ \\
\hline 8 & $21.9^{\mathrm{a}}$ & $14.6^{\mathrm{ab}}$ & $2.28^{\mathrm{ab}}$ & $15.1^{\mathrm{ab}}$ & $1.4^{\mathrm{ab}}$ \\
\hline 10 & $24.0^{\mathrm{a}}$ & $14.3^{\mathrm{ab}}$ & $2.25^{\mathrm{ab}}$ & $12.8^{\mathrm{ab}}$ & $1.3^{\mathrm{ab}}$ \\
\hline 11 & $19.3^{\mathrm{a}}$ & $16.2^{\mathrm{ab}}$ & $2.55^{\mathrm{a}}$ & $12.7^{\mathrm{ab}}$ & $1.4^{\mathrm{ab}}$ \\
\hline
\end{tabular}

Explanation: Means followed by the same letters do not differ significantly at $p=0.05$ 
which are necessary for plants and they minimize the risk of a deficit of nutrients. Nitrogen is usually decisive to the yield of crops. The absorbability of nitrogen from organic fertilizers is usually lower than from mineral fertilizers [49].

Our observations confirm the statement above as the highest yield of fresh and dry weight of beet roots and leaves was noted in the combination with mineral fertilization (Table 6).

No significant influence of the fertilizers on plant density was observed. In the control sample it was 22.7 pieces per $\mathrm{m}^{2}$, whereas in the combinations with the fertilizers it ranged from 17.4 to 24.0 pieces per $\mathrm{m}^{2}$ (Table 6).

Apart from that, the study proved that all the fertilizers had a positive effect on the yield of roots, but the increase in the yield was statistically significant only in the variants where mineral fertilization had been applied, i.e., in the combination with the onion waste compost inoculated with isolates T1 and T3 and in the one with the tomato waste compost inoculated with isolates $\mathrm{T} 1$ and $\mathrm{T} 2$. There were similar dependences observed about the yield of the dry weight of beet roots. There was also a significant increase in the yield where the tomato waste compost inoculated with isolate $\mathrm{T} 2$ had been applied.

The influence of the fertilizers on the yield of beet leaves was less than the influence observed about the yield of roots. Only mineral fertilization was proven to cause an increase of $7.7 \mathrm{Mg} \mathrm{ha}^{-1}$. This type of fertilization also resulted in a significant increase in the yield of dry weight of leaves as compared with the control sample.

The findings of our study let us conclude that the influence of organic fertilizers is very variable and largely depends on the composition of fertilizers and the method and length of their storage. In our study vegetable waste composts and the standard organic fertiliser, i.e., manure, had little influence on the yield of plants. However, the aim of organic fertilization is not only to increase yield but also to enrich soil with organic matter and improve its physical properties. As shown by the study by Paavola and Rintala [50], the replacement of fresh natural fertilizers with fermented mass or composts considerably reduces the emission of noxious odours and the spread of pathogens. It also reduces the penetration of nitrates (V) into the soil profile, which results in better quality plant yield.

The favourable yield-forming effect of Trichoderma sp. isolates, which were applied to the soil in the vegetable waste composts in our study, provides new possibilities to acquire valuable organic fertilizers for growing red beets.

The favourable influence of Trichoderma sp. on the growth and yield of vegetable plants was also reported in studies by Bal and Altintas [51] and Vinale et al. [52]. Also, according to Haque et al. [53], efficient use of Trichoderma-enriched compost may increase yield, reduce the uses of $\mathrm{N}$ fertilizers, reduce soil-borne pathogens, and improve soil health.

\section{Conclusions}

The counts of the microorganisms under analysis (the total count of moulds and the counts of Trichoderma sp., Fusarium sp., and Alternaria sp.) were most strongly modified by mineral fertilizer and manure applied to the soil. The vegetable waste composts applied to the soil did not prove to stimulate the growth and development of Alternaria sp. or Fusarium sp. in the soil. Apart from the mineral and manure fertilization, the phase of plant development proved to be the main factor affecting the proliferation of these microorganisms. The Trichoderma sp. isolates also exhibited diversified influence on the count of plant pathogens. The proliferation of Fusarium $\mathrm{sp}$. in the soil was limited when strain T3 and a mixture of isolates T1 and T3 were applied with the onion waste compost. Apart from that, the research did not prove any antagonistic effect of Trichoderma sp. strains on the count of Alternaria sp. pathogens in the soil.

The research findings revealed that enzymatic activity, which plays a prominent role in immobilizing and mineralizing plant nutrients in soil, was most stimulated by the addition of manure, followed by the addition of tomato waste composts. The yield of the plant roots and leaves was most influenced by mineral fertilization. However, the application of the composts which had been simultaneously inoculated with two strains (i.e., T1 and $\mathrm{T} 2$ or T1 and T3) also caused a statistically significant increase in the yield of fresh weight of beetroots.

Our study proved that vegetable waste could be used as a carrier for applying Trichoderma sp. isolates into soil. It may increase the yield of plants and limit the development of selected plant pathogens, but it is important to select the right strain of Trichoderma sp.

\section{Acknowledgements}

Our research was conducted as part of a project of the National Centre for Research and Development, No. UDA-POIG.01.03.01-00-129/09-09: "Polish Strains of Trichoderma in Plant Protection and Organic Waste Handling."

\section{References}

1. POLISH CROP PROTECTION PRODUCTS REGULATION of 8 March 2013, Official Journal, Pos. 455, 2013 [In Polish].

2. AGRICULTURE AND RURAL ECONOMY IN POLAND. Ministry of Agriculture and Rural Development, ISSN 14270757; 130, Warsaw, 2013 [In Polish].

3. DIRECTIVE 2009/128/EC of the European Parliament and of the Council establishing a framework for Community action to achieve the sustainable use of pesticides. Official Journal of the European Union L 309, 71, 24 November 2009. 
4. YOU J., ZHANG J., WU M., YANG L., CHEN W., LI G. Multiple criteria-based screening of Trichoderma isolates for biological control of Botrytis cinerea on tomato. Biological Control. 101, 31, 2016.

5. SZCZECH M., STANIASZEK M., HABDAS H., ULIŃSKI Z., SZYMAŃSKI J. Trichoderma spp.-The cause of green mold on Polish mushroom farms. Veg. Crops Res. Bull. 69,105, 2008

6. SCHUSTER A., SCHMOLL M. Biology and biotechnology of Trichoderma. Appl Microbiol Biotechnol. 87 (3), 787, 2010

7. TOGHUEO R.M.K., EKE P., ZABALGOGEAZCOA I., RODRÍGUEZ VÁZQUEZ DE ALDANA B., NANA L.W., BOYOM F.F. Biocontrol and growth enhancement potential of two endophytic Trichoderma spp. from Terminalia catappa against the causative agent of Common Bean Root Rot (Fusarium solani). Biological Control. 96, 8, 2016.

8. ZHAO W., QI L. Study of the siderophore-producing Trichoderma asperellum $\mathrm{Q} 1$ on cucumber growth promotion under salt stress. J Basic Microb. 53, 355, 2013.

9. MUKHERJEE P.K., HORWITZ B.A., KENERLEY C.M. Secondary metabolism in Trichoderma - A genomic perspective. Microb. 158, 35, 2012.

10. HAQUE MD.M., ILIAS G.N.M., MOLLA A.H. Impact of Trichoderma - enriched biofertilizer on the growth and yield of mustard (Brassica rapa L.) and tomato (Solanum lycopersicon Mill.). Sci. J Krishi Found. 10 (2), 109, 2012.

11. BETTIOL W., MORANDI M.A.B. Trichoderma in Brazil: History, research, commercialization and perspectives, in: Duffy B., Maurhoffer M., Kell C., Gessler C. (Eds.), Molecular tools for understanding and improving biocontrol, Meeting of the Working Group "Biological control of fungal and bacterial plant pathogens"; 49, Interlaken, 2008.

12. PIETR S., ŚLUSARSKI C. The Possibilities of using fungi of the genus Trichoderma, Horticult. Password 4, 27, 2007 [In Polish].

13. PN-ISO 10381-2:2007 Soil quality - Collecting Samples Part 2: The Rules of Collection Techniques. (in Polish)

14. MARTIN J. P. Use of acid, rose bengal and streptomycin in the plate method for estimating soil fungi. Soil Sci. 69, 215, 1950.

15. AMANN R.I., KRUMHOLZ L., STAHL D.A. Fluorescentoligonucleotide probing of whole cells for determinative, phylogenetic, and environmental studies in microbiology, J. Bacteriol. 172 (2), 762, 1990.

16. SIDDIQUEE S., YUSOF N.A., SALLEH A.B., TAN S.G., BAKAR F.A., HENG L.Y. DNA hybridization based on Trichoderma harzianum gene probe immobilization on selfassembled monolayers on a modified gold electrode. Sensors and Actuators B: Chemical. 147, 198, 2010.

17. KOMADA H. Development of a selective medium for quantitative isolation of Fusarium oxysporum from natural soil. Rev. Plant Prot. Res. 8, 114, 1975.

18. HONG B., PRYOR M. Development of selective media for the isolation and enumeration of Alternaria species from soil and plant debris. Can. J. Microbiol. 50, 461, 2004.

19. ELLIS M.B. More Dematiaceous hyphomycetes, Commonwealth Mycological Institute; 507, Kew, Surrey, England, 1976.

20. DOMSCH K.H., GAMS W., ANDERSONT.H.Compendium of soil fungi, ed. Academic Press; 406, San Francisco, 1993.

21. KOZŁOWSKA M. Hypochytridioromycota, in: Mułenko W., Majewski T., Ruszkiewicz-Michalska M., ed. A preliminary checklist of micromycetes in Poland, Biodiversity of Poland. W. Szafer Institute of Botany, Polish Academy of Sciences, Kraków, 9, 13, 2008 [In Polish].
22. THALMANN A. Zur Methodik der Bestimmung der Dehydrogenase Aktivität in Boden mittels Triphenyltetrazoliumchlorid (TTC), Landwirt. Forsch. 21, 249, 1968.

23. JOHNSON J.I., TEMPLE K.L. Some variables affecting the measurements of catalase activity in soil. Soil Sci. Soc. Am. Proc. 28, 207, 1964.

24. STEFANIC F., ELLADE G., CHIRNAGEANU J. Researches concerning a biological index of soil fertility, in: Nemes M. P., Kiss S., Papacostea P., Stefanic C., Rusan M., ed. Proceeding of the Fifth Symposium of Soil Biology, Romanian National Society of Soil Science; 35, Bucharest, Romania, 1984.

25. AHEMAD M., KHAN M.S. Effect of insecticide-tolerant and plant growth-promoting Mesorhizobium on the performance of chickpea grown in insecticide stressed alluvial soils. J Crop Sci. Biotechnol. 12, 213, 2009.

26. WOLNA-MARUWKA A., KLAMA J., NIEWIADOMSKA A. Effect of the fertilization with the communal sewage sludge on the respiration activity and counts of selected microorganisms in the grey brown podzolic soil. Polish J Environ. Stud. 16 (6), 899, 2007.

27. WYSZKOWSKA J., KUCHARSKI J., JANKOWSKI K., KIJEWSKI $€$. The influence of post-harvest residue on the activity of soil enzymes. Adv. Agri. Sci. Probl. Issues. 537, 403, 2009 [In Polish].

28. VALLANCE J., DENIEL F., FLOCH G. L., REY P. Pathogenic and A. beneficial microorganisms in soilless cultures. Agron. Sustain. Dev. 31, 191, 2011.

29. KUCHARSKI J., WYSZKOWSKA J. The influence of agriculture on the microbiological soils properties, in: The impact of agriculture on the environment in terms of climate change. IUNG-PIB, Studies and Dissertation, Pulawy, 19, 37, 2010 [In Polish].

30. GARBEVA P., VAN VEEN J.A., VAN ELSAS J.D. Microbial diversity in soil: Selection of microbial populations by Plant and Soil Type and Implications for Disease Suppressiveness. Annu. Rev. Phytopathol. 42, 243, 2004.

31. KREDICS L., ANTAL Z., MANCZINGER L., SZEKERES A., KEVEI F., NAGY E. Trichoderma strains with biocontrol potential. Food Technol. Biotechnol. 41, (1), 37, 2003.

32. UTAMA M.S., WILLS R.B.H, BEN-YEHOSHUA S., KUEK C. In vitro efficacy of plant volatiles for inhibiting the growth of fruit and vegetable decay microorganisms. J. Agric. Food Chem. 50, 6371, 2002.

33. STEINKA I., KUKUŁOWICZ A. The biostatic influence of plant pulp and solutions on staphylococci. Bromat. Chem. Toksykol. XLI (2), 191, 2008.

34. LEE J. Effect of application methods of organic fertilizer on growth, soil chemical properties and microbial densities in organic bulb onion production Sci. Hortic. 124, 299, 2010.

35. GEISSELER D., SCOW K. M. Long-term effects of mineral fertilizers on soil microorganisms - A review. Soil Biology and Biochemistry. 75, 54, 2014.

36. HEINZE S., RAUPP J., JOERGENSEN R. G. Effects of fertilizer and spatial heterogeneity in soil $\mathrm{pH}$ on microbial biomass indices in a long-term field trial of organic agriculture. Plant and Soil. 328 (1), 203, 2010.

37. LOU J., FU L., PENG Y., ZHOU L. Metabolites from Alternaria fungi and their bioactivities. Molec. 18 (5), 5891, 2013.

38. BART P.H.J.T. Pathogen profile Alternaria spp.: from general saprophyte to specific parasite. Mole. Plant Path. 4 (4), 225, 2003. 
39. WOLNA-MARUWKA A., NIEWIADOMSKA A., KLAMA J. Biological activity of grey-brown podzolic soil organically fertilized for maize cultivation in monoculture. Polish J Environ. Stud. 18 (5), 931, 2009.

40. GÓRSKA E. B., STĘPIEŃ W., RUSSEL S. Effect of sewage sludge, chicken droppings and Dano compost addition on microbiological activity of the soil and yields of the red bee. Adv. Agri. Sci. Probl. Issues. 520, 287, 2007 [In Polish).

41. TAGOE D.N.A., NYARKO H.D., ALPAKA R. A comparison of the antifungal properties of onion (Allium cepa), ginger (Zingiber officinale) and garlic (Allium sativum) against Aspergillus flavus, Aspergillus niger and Cladosporium herbarum. Res. J Med. Plant. 5, 281, 2011.

42. STONE G., VALLAD G.E., COOPERBAND L.R., ROTENBERG D., DARBY H.M., JAMES R.V., STEVENSON W.R., GOODMAN R.M. Effect of organic amendments on soilborne and foliar diseases in field-grown snap bean and cucumber. Plant Dis. 87 (9), 1037, 2003.

43. WYSZKOWSKA J., WYSZKOWSKI M. Activity of soil dehydrogenases, urease and acid and alkaline phosphatases in soil polluted with petroleum. J Toxicol. Environ. Health, Part A. 73 (17-18), 1202, 2010.

44. MEENA M.D., JOSHI P.K., JAT H.S., CHINCHMALATPURE A. R., NARJARY B., SHEORAN P., SHARMA D.K. Changes in biological and chemical properties of saline soil amended with municipal solid waste compost and chemical fertilizers in a mustard-pearl millet cropping system. Catena. 140, 1, 2016.

45. ACOSTA-MARTINEZ V., TABATABAI M.A. Enzyme activities in a limed agricultural soil. Biol. Fert. Soils. 31, 85, 2000.
46. WOLNA-MARUWKA A., SCHROETER-ZAKRZEWSKA A., BOROWIAK K., NIEWIADOMSKA A. Impact of microbiological inoculum on numbers and activity of microorganisms in peat substrate and on growth and flowering of scarlet sage. Polish J Environ. 21 (6), 357, 2012.

47. YAO X., MIN H., LU Z., YUAN H. Influence of acetamipiryd on soil enzymatic activity and respiration. Eur. J. Soil Biol. 42, 120, 2006.

48. WATTS D.B., TORBERT H.A., FENG Y., PRIOR A. Soil microbial community dynamics as influenced by composted dairy manure, soil properties and landscape position. Soil Sci. 175 (10), 474, 2010.

49. MEENA V.S., MAURYA B.R., MEENA R.S., MEENA S.K., SINGH N.P., MALIK V.K., KUMAR V., JAT L.K. Microbial dynamics as influenced by concentrate manure and inorganic fertilizer in alluvium soil of Varanasi, India. Afr. J Microbiol. Res. 8 (3), 257, 2014.

50. PAAVOLA T., RINTALA J. Effects of storage on characteristics and hygienic quality of digestates from four co-digestion concepts of manure and biowaste. Bioresour. Technol. 99, 7041, 2008.

51. BAL U., ALTINTAS S. A positive side effect from Trichoderma harzianum, the biological control agent: Increased yield in vegetable crops. J Environ. Prot. Ecol. 7, 383, 2006.

52. VINALE F., SIVASITHAMPARAM K., GHISALBERTI E.L., MARRA R., WOO S.L., LORITO M. Trichodermaplant-pathogen interactions. Soil Biol. Biochem. 40, 1, 2008.

53. HAQUE MD.M., ILIAS G.N.M, MOLLA A.H. Impact of Trichoderma-enriched biofertilizer on the growth and yield of mustard (Brassica rapa L.) and tomato (Solanum lycopersicon Mill.). Sci. J Krishi Found. 10, (2), 109, 2012. 